\title{
The First Nickelacarborane with closo-nido Structure
}

\author{
Ekaterina P. Andreichuk ${ }^{1,2}$, Sergey A. Anufriev ${ }^{1}$, Kyrill Yu. Suponitsky ${ }^{1,3}$ and \\ Igor B. Sivaev $1, *$ (1)
}

1 A.N. Nesmeyanov Institute of Organoelement Compounds, Russian Academy of Sciences, 28 Vavilov Street, 119991 Moscow, Russia; katenino16@gmail.com (E.P.A.); trueman476@mail.ru (S.A.A.);

kirshik@yahoo.com (K.Y.S.)

2 Higher Chemical College at the Russian Academy of Sciences, D.I. Mendeleev Russian Chemical

Technological University, 9 Miusskaya Square, 125047 Moscow, Russia

3 N.S. Kurnakov Institute of General and Inorganic Chemistry, Russian Academy of Sciences,

31 Leninskii Avenue, 119991 Moscow, Russia

* Correspondence: sivaev@ineos.ac.ru; Tel.: +7-916-590-2025

Academic Editor: Michael A. Beckett

Received: 25 November 2020; Accepted: 18 December 2020; Published: 18 December 2020

\begin{abstract}
The first nickelacarborane with closo-nido structure $\left[10^{\prime}, 11^{\prime}-(\mathrm{Py})_{2}-3,9^{\prime}-\mathrm{Ni}\left(1,2-\mathrm{C}_{2} \mathrm{~B}_{9} \mathrm{H}_{11}\right)\left(7^{\prime}, 8^{\prime}-\right.\right.$ $\left.\left.\mathrm{C}_{2} \mathrm{~B}_{8} \mathrm{H}_{8}\right)\right]$ was isolated from the reaction of nickel(IV) bis(dicarbollide) with pyridine. The molecular structure of this complex was determined by single crystal $\mathrm{X}$-ray diffraction. The nickel atom is a common vertex for the closo- $\mathrm{NiC}_{2} \mathrm{~B}_{9}$ cluster and the nido- $\mathrm{NC}_{2} \mathrm{~B}_{8}$ cluster where it is located together with carbon atoms in the open $\mathrm{NiC}_{2} \mathrm{~B}_{2}$ pentagonal face. It is assumed that its formation proceeds through the nucleophile-induced removal of the $\mathrm{B}(6) \mathrm{H}$ vertex followed by rearrangement of the forming 11-vertex cluster, which most likely proceeds through a sequence of closing and opening reactions.
\end{abstract}

Keywords: nickelacarboranes; nickel bis(dicarbollide); pyridine derivative; polyhedral contraction; single crystal X-ray diffraction

\section{Introduction}

Due to the practically unlimited possibility of varying the structure of carboranes, including by replacing hydrogen atoms with various groups, transition metal complexes with carborane ligands are one of the most exciting areas of modern chemistry [1-3]. In addition to purely academic interest, a number of them show excellent prospects for practical use. Thus, nickel bis(dicarbollide) and its derivatives [4] attract interest of researchers due to their potential applications in materials science, including molecular switches [5-8], solar cells $[9,10]$ and conductive metal-organic frameworks [11]. At the same time, the available information on the stability of these complexes is fragmentary and rather contradictory [12-15]. This prompted us to study the stability of nickel(IV) bis(dicarbollide) under various conditions. Earlier, we found that boiling nickel bis(dicarbollide) in ethanol leads to its decomposition with the formation of a mixture of nido-carborane and its 3-ethoxy derivative as the main products [16].

In this contribution we report the formation of the first nickelacarborane with a closo-nido structure in the reaction of nickel(IV) bis(dicarbollide) with boiling pyridine.

\section{Results and Discussion}

It was found that prolonged refluxing nickel(IV) bis(dicarbollide) (1) in pyridine leads to its complete transformation into a mixture of various nickelacarboranes, mainly of paramagnetic nature. The separation of this mixture by column chromatography on silica gave a diamagnetic nickelacarborane 
$\left[10^{\prime}, 11^{\prime}-(\mathrm{Py})_{2}-3,9^{\prime}-\mathrm{Ni}\left(1,2-\mathrm{C}_{2} \mathrm{~B}_{9} \mathrm{H}_{11}\right)\left(7^{\prime}, 8^{\prime}-\mathrm{C}_{2} \mathrm{~B}_{8} \mathrm{H}_{8}\right)\right](2)$, the structure of which was established by single crystal X-ray diffraction. The reaction is characterized by good reproducibility with an isolated yield of 2 ranging from 19 to $23 \%$ (Scheme 1 ).

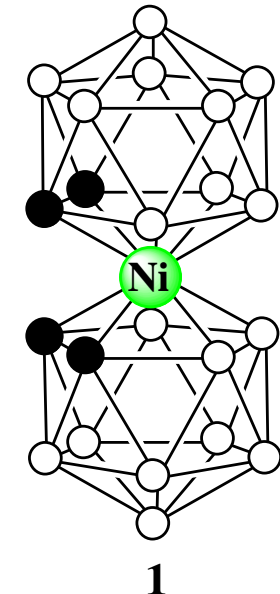

1

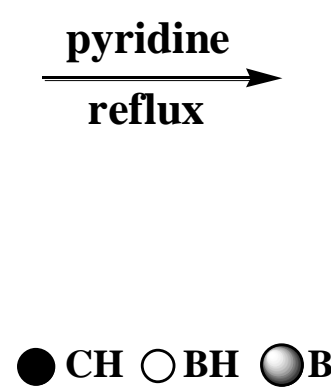

Scheme 1. Reaction of nickel(IV) bis(dicarbollide) with pyridine.
+ other products

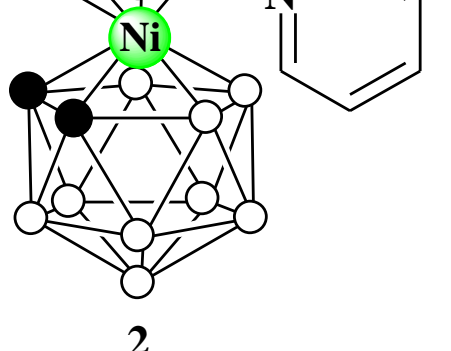

\section{ther products}

The ${ }^{1} \mathrm{H}$ NMR spectrum of 2 contains a set of signals from two different $N$-substituted pyridines in the range of 8.9-7.6 ppm and four signals from different $\mathrm{CH}$ groups of carborane ligands at 3.55, 3.33, 2.80 and $1.87 \mathrm{ppm}$, while the ${ }^{11} \mathrm{~B}$ NMR spectrum contains two sets of signals corresponding to symmetrical and asymmetrical carborane ligands (See Supplementary Materials). It should be noted that determination of the structure of metallacarboranes containing carborane ligands of different geometry is a difficult task that normally cannot be solved using methods of NMR spectroscopy due to signal overlap and, therefore, requires single crystal X-ray diffraction study [17-22].

An asymmetric unit cell of the complex 2 contains one molecule (Figure 1). In the structure of the complex, the nickel atom is a common vertex for the closo- $\mathrm{NiC}_{2} \mathrm{~B}_{9}$ cluster and the nido- $\mathrm{NC}_{2} \mathrm{~B}_{8}$ cluster, where it is located together with carbon atoms in the open $\mathrm{NiC}_{2} \mathrm{~B}_{2}$ pentagonal face. Each of the remaining two boron atoms on the pentagonal face is bonded to a pyridine molecule.

The Ni-B bonds in the nido-fragment (2.093(3)-2.119(3) $\AA$ ) are only slightly shorter than in the closo-fragment (2.103(2)-2.127(3) $\AA$ ), while the Ni-C bond lengths differ more significantly (2.002(2) and 2.105(2)-2.170(2) $\AA$ for the nido- and closo-fragments, respectively). The same trend is observed also for the C-C bond lengths (1.508(3) and 1.573(3) $\AA$ for the nido- and closo-fragments, respectively). The $B-N$ lengths equal 1.553(3) and 1.561(3) $\AA$, that are somewhat shorter than in a related cobaltacarborane $\left(\mathrm{Et}_{4} \mathrm{~N}\right)\left[11^{\prime}-\mathrm{Py}-3,9^{\prime}-\mathrm{Co}\left(1,2-\mathrm{C}_{2} \mathrm{~B}_{9} \mathrm{H}_{11}\right)\left(7^{\prime}, 8^{\prime}-\mathrm{C}_{2} \mathrm{~B}_{8} \mathrm{H}_{10}\right)\right]$ (1.592(11) $\AA$ ) [23], but close to those found in pyridinium derivatives of nido-carborane [9-Py-7,8- $\left.\mathrm{C}_{2} \mathrm{~B}_{9} \mathrm{H}_{11}\right](1.546(2) \AA)$ [24] and metallacarboranes [4-Py-3- $\left.\left(\mathrm{C}_{4} \mathrm{Me}_{4}\right)-3,1,2-\mathrm{CoC}_{2} \mathrm{~B}_{9} \mathrm{H}_{10}\right]$ (1.548(3) $\AA$ ) [24], [8-Py-3,3'-Co(1,2- $\left.\mathrm{C}_{2} \mathrm{~B}_{9} \mathrm{H}_{10}\right)\left(1^{\prime}, 2^{\prime}-\mathrm{C}_{2} \mathrm{~B}_{9} \mathrm{H}_{11}\right)$ ] $(1.556(5) \AA)$ [25], [8-Py-3,3'-Fe(1,2- $\left.\mathrm{C}_{2} \mathrm{~B}_{9} \mathrm{H}_{10}\right)\left(1^{\prime}, 2^{\prime}-\mathrm{C}_{2} \mathrm{~B}_{9} \mathrm{H}_{11}\right)$ ] (1.548(6) and 1.553(6) $\AA$ ) [25]. The relative orientation of the carborane ligands can be described by the pseudotorsion angle $\mathrm{C} 1 \mathrm{Centroid}$ (C1-C2-B7-B8-B4) Ni1-B10' that is equal to 104.0 (2) ${ }^{\circ}$. Slightly shortened intramolecular CH...HB contacts were found between the pyridine substituent closest to the metal atom and the dicarbollide ligands. To assess their possible contribution to the stabilization of the observed conformation of complex 2, we carried out its QTAIM (quantum theory of atoms in molecules) study [26,27]. Energy of intramolecular noncovalent interactions was estimated based on their correlation with the energy density function [28] that was found to be reliable for different types of weak noncovalent interactions [29-31]. Two CH...HB noncovalent contacts (shown in Figure 1) were observed (B5'-H5' $\cdots \mathrm{H} 3 \mathrm{~A}-\mathrm{C} 3,2.40 \AA$,

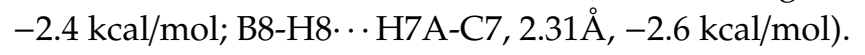




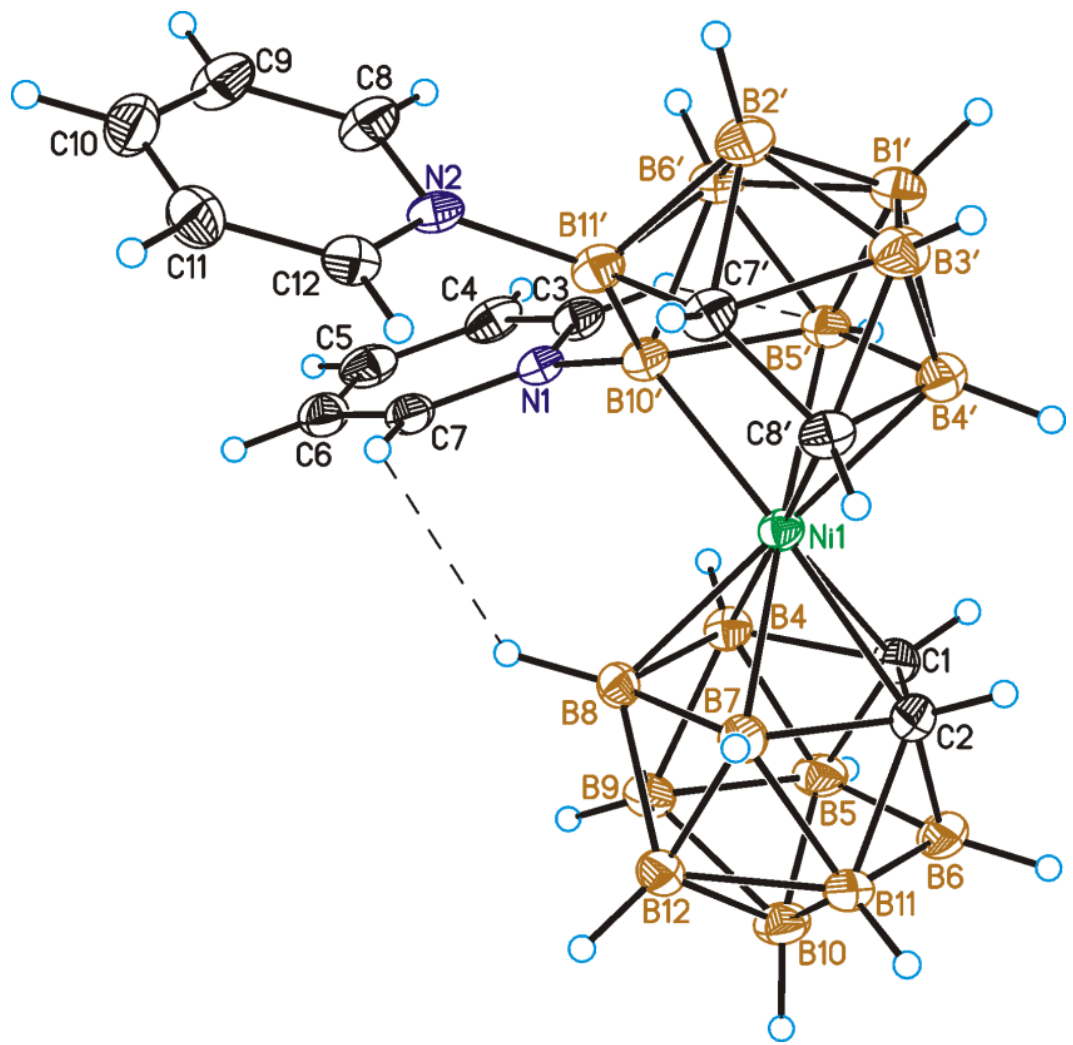

Figure 1. General view of complex 2 showing atomic numbering intramolecular $\mathrm{CH} \cdots \mathrm{HB}$ contacts. Thermal ellipsoids are drawn at 50\% probability level.

It should be noted that neither other transition metal bis(dicarbollide) complexes, nor ortho-carborane itself, do not undergo deboronation with pyridine, whereas $C$-halogen derivatives were found to be accessible for nucleophilic attack of pyridine and its derivatives [32]. Complex $\mathbf{2}$ is the first example of a nickelacarborane in which the metal atom is common to both the closo-icosahedral cluster and the nido-cluster formed by removing one vertex from the icosahedron. A related cobaltacarborane $\left[11^{\prime}-\mathrm{Py}-3,9^{\prime}-\mathrm{Co}\left(1,2-\mathrm{C}_{2} \mathrm{~B}_{9} \mathrm{H}_{11}\right)\left(7^{\prime}, 8^{\prime}-\mathrm{C}_{2} \mathrm{~B}_{8} \mathrm{H}_{10}\right)\right]^{-}$(3) was earlier prepared by removing one $\mathrm{BH}$ vertex on heating the parent cobalt bis(dicarbollide) $\left[3,3^{\prime}-\mathrm{Co}\left(1,2-\mathrm{C}_{2} \mathrm{~B}_{9} \mathrm{H}_{11}\right)_{2}\right]^{-}$in a $25 \%$ aqueous solution of potassium hydroxide at $95{ }^{\circ} \mathrm{C}$, followed by the oxidation of the formed nido- structure to the closo- one with $30 \%$ hydrogen peroxide, and the reaction with pyridine, which leads to the opening of the 11-vertex metallacarborane the substitution of one hydrogen atom with pyridine [33,34]. In general, the formation of complex 2 can be described as a polyhedral contraction reaction $[33,35,36]$.

Taking into account that the BH group at position 6 is the most susceptible to nucleophilic attack in the 3,1,2-MC $\mathrm{MC}_{2}$ metallacarboranes, we believe the formation of complex 2 should also proceed through the removal of this vertex followed by rearrangement of the 11-vertex cluster, which most likely proceeds through a sequence of closing and opening reactions, rather than via detachment and reattachment of the carborane ligand. Therefore, it is reasonable to assume that other formed nickelacarboranes are related to cobaltacarboranes, which are intermediate products of the formation of complex 3 . The identification of these products is in progress.

\section{Materials and Methods}

\subsection{General Methods}

Nickel(IV) bis(dicarbollide) (1) was prepared according to the published procedure [37]. The reaction progress was monitored by thin layer chromatography (Merck F254 silica gel on aluminum 
plates) and visualized using $0.5 \% \mathrm{PdCl}_{2}$ in $1 \% \mathrm{HCl}$ in aq. $\mathrm{MeOH}(1: 10)$. Acros Organics silica gel $(0.060-0.200 \mathrm{~mm})$ was used for column chromatography. The NMR spectra at $400 \mathrm{MHz}\left({ }^{1} \mathrm{H}\right), 128 \mathrm{MHz}$ $\left({ }^{11} \mathrm{~B}\right)$ and $100 \mathrm{MHz}\left({ }^{13} \mathrm{C}\right)$ in acetone- $d_{6}$ were recorded with a Varian Inova 400 spectrometer. The residual signal of the NMR solvent relative to tetramethylsilane was taken as the internal reference for ${ }^{1} \mathrm{H}$ and ${ }^{13} \mathrm{C}$ NMR spectra. ${ }^{11} \mathrm{~B}$ NMR spectra were referenced using $\mathrm{BF}_{3} \cdot \mathrm{Et}_{2} \mathrm{O}$ as an external standard.

The X-ray diffraction experiment for compound 2 was carried out using a SMART APEX2 CCD diffractometer $(\lambda(\mathrm{Mo}-\mathrm{K} \alpha)=0.71073 \AA$, graphite monochromator, $\omega$-scans $)$ at $120 \mathrm{~K}$. Collected data were processed by the SAINT and SADABS programs incorporated into the APEX2 program package [38]. The structure was solved by direct methods and refined by the full-matrix least-squares procedure against $F^{2}$ in anisotropic approximation. The refinement was carried out with the SHELXTL program [39]. The CCDC number (2046492) contain the supplementary crystallographic data for this paper. These data can be obtained free of charge via www.ccdc.cam.ac.uk/data_request/cif.

\subsection{Reaction of Nickel(IV) Bis(Dicarbollide) with Pyridine}

A solution of nickel(IV) bis(dicarbollide) $(50 \mathrm{mg}, 0.3 \mathrm{mmol})$ in $30 \mathrm{~mL}$ of pyridine was stirred under reflux for $50 \mathrm{~h}$. Thereafter, solution was cooled to room temperature and concentrated under reduced pressure. The crude product was subjected to column chromatography on silica using of dichloromethane as eluent. The third boron-containing fraction gave dark crystals of 2 (17 $\mathrm{mg}$, yield 23\%). ${ }^{1} \mathrm{H}$ NMR: $\delta 8.89\left(\mathrm{~d}, 2 \mathrm{H}, \mathrm{J}=7.0 \mathrm{~Hz}, o-\mathrm{CH}_{\mathrm{Py}}\right), 8.70\left(2 \mathrm{H}, \mathrm{d}, \mathrm{J}=6.8 \mathrm{~Hz}, o-\mathrm{CH}_{\text {Py }}\right), 8.46(1 \mathrm{H}, \mathrm{t}$, $\left.\mathrm{J}=7.0 \mathrm{~Hz}, p-\mathrm{CH}_{\mathrm{Py}}\right), 8.19\left(1 \mathrm{H}, \mathrm{t}, \mathrm{J}=6.8 \mathrm{~Hz}, p-\mathrm{CH}_{\mathrm{Py}}\right), 8.01\left(2 \mathrm{H}, \mathrm{t}, \mathrm{J}=7.0 \mathrm{~Hz}, m-\mathrm{CH}_{\mathrm{Py}}\right), 7.60(2 \mathrm{H}, \mathrm{t}$, $\left.\mathrm{J}=6.8 \mathrm{~Hz}, m-\mathrm{CH}_{\mathrm{Py}}\right), 4.0-0.4\left(15 \mathrm{H}, \mathrm{br}, \mathrm{B} H_{\text {Carb }}\right), 3.55\left(1 \mathrm{H}, \mathrm{s}, \mathrm{CH}_{\text {Carb }}\right), 3.33\left(1 \mathrm{H}, \mathrm{s}, \mathrm{CH}_{\text {Carb }}\right), 2.80(1 \mathrm{H}, \mathrm{s}$, $\left.\mathrm{CH}_{\text {Carb }}\right), 1.87\left(1 \mathrm{H}, \mathrm{s}, \mathrm{CH}_{\text {Carb }}\right)$ ppm; ${ }^{11} \mathrm{~B}$ NMR: $\delta 15.2(1 \mathrm{~B}, \mathrm{~s}, B-\mathrm{N}), 7.7(1 \mathrm{~B}, \mathrm{~d}, \mathrm{~J}=116 \mathrm{~Hz}), 2.3(1 \mathrm{~B}, \mathrm{~d}$, $\mathrm{J}=149 \mathrm{~Hz}), 0.8(1 \mathrm{~B}, \mathrm{~s}, \mathrm{~B}-\mathrm{N}),-2.1(1 \mathrm{~B}, \mathrm{~d}, \mathrm{~J}=146 \mathrm{~Hz}),-4.6(2 \mathrm{~B}, \mathrm{~d}, \mathrm{~J}=137 \mathrm{~Hz}),-6.4(2 \mathrm{~B}, \mathrm{~d}, \mathrm{~J}=146 \mathrm{~Hz})$, $-7.8(1 \mathrm{~B}, \mathrm{~d}, \mathrm{~J}=114 \mathrm{~Hz}),-10.9(1 \mathrm{~B}, \mathrm{~d}, \mathrm{~J}=133 \mathrm{~Hz}),,-17.4(3 \mathrm{~B}, \mathrm{~d}, \mathrm{~J}=138 \mathrm{~Hz}),-20.2(1 \mathrm{~B}, \mathrm{~d}, \mathrm{~J}=163 \mathrm{~Hz})$, $-22.9(1 \mathrm{~B}, \mathrm{~d}, \mathrm{~J}=163 \mathrm{~Hz}),-31.6(1 \mathrm{~B}, \mathrm{~d}, \mathrm{~J}=139 \mathrm{~Hz}) \mathrm{ppm} ;{ }^{13} \mathrm{C}$ NMR: $\delta 149.8\left(o-\mathrm{CH}_{\mathrm{Py}}\right), 146.6\left(o-\mathrm{CH}_{\mathrm{Py}}\right)$, $143.5\left(p-\mathrm{CH}_{\mathrm{Py}}\right), 143.1\left(p-\mathrm{CH}_{\mathrm{Py}}\right), 128.6\left(m-\mathrm{CH}_{\mathrm{Py}}\right), 126.1\left(m-\mathrm{CH}_{\mathrm{Py}}\right), 54.1\left(\mathrm{CH}_{\mathrm{Carb}}\right), 45.7\left(\mathrm{CH}_{\mathrm{Carb}}\right), 40.9$ $\left(\mathrm{CH}_{\mathrm{Carb}}\right), 40.2\left(\mathrm{CH}_{\mathrm{Carb}}\right)$ ppm. Crystallographic data: $\mathrm{C}_{14} \mathrm{H}_{29} \mathrm{~B}_{17} \mathrm{~N}_{2} \mathrm{Ni}$ are monoclinic, space group $P 2_{1} / n$ : $a=13.0440(8) \AA, b=9.8669(6) \AA, c=18.6798(11) \AA, \beta=98.2660(10)^{\circ}, V=2379.2(2) \AA^{3}, Z=4, M=467.87$, $d_{\text {cryst }}=1.306 \mathrm{~g} \cdot \mathrm{cm}^{-3} \cdot w R 2=0.0990$ calculated on $F_{h k l}^{2}$ for all 6244 independent reflections with $2 \theta<56.4^{\circ},\left(G O F=1.020, R=0.0408\right.$ calculated on $F_{h k l}$ for 4310 reflections with $\left.I>2 \sigma(I)\right)$.

Supplementary Materials: The following are available online, NMR spectra of compound 2.

Author Contributions: Synthesis, E.P.A.; NMR spectroscopy study, S.A.A.; single crystal X-ray diffraction, K.Y.S.; supervision and manuscript concept, I.B.S. All authors have read and agreed to the published version of the manuscript.

Funding: This work was supported by the Russian Science Foundation (Grant No. 16-13-10331).

Acknowledgments: The NMR spectroscopy and X-ray diffraction data were obtained by using equipment from the Center for Molecular Structure Studies at A.N. Nesmeyanov Institute of Organoelement Compounds, operating with support from the Ministry of Science and Higher Education of the Russian Federation.

Conflicts of Interest: The authors declare no conflict of interest. The funders had no role in the design of the study; in the collection, analyses, or interpretation of data; in the writing of the manuscript, or in the decision to publish the results.

\section{References}

1. Grimes, R.N. Transition metal metallacarbaboranes. In Comprehensive Organometallic Chemistry II, Volume 1; Housecraft, C.E., Ed.; Pergamon Press: Oxford, UK, 1995; pp. 373-430. [CrossRef]

2. Hosmane, N.S.; Maguire, J.A. Metallacarboranes of $d$ - and $f$-block metals. In Comprehensive Organometallic Chemistry III, Volume 3; Housecraft, C.E., Ed.; Elsevier Science: Amsterdam, The Netherlands, 2007; pp. 175-264. [CrossRef]

3. Grimes, R.N. Carboranes, 3rd ed.; Academic Press: London, UK, 2016; pp. 711-903. [CrossRef] 
4. Sivaev, I.B.; Bregadze, V.I. Chemistry of nickel and iron bis(dicarbollides). A review. J. Organomet. Chem. 2000, 614-615, 27-36. [CrossRef]

5. Hawthorne, M.F.; Zink, J.I.; Skelton, J.M.; Bayer, M.J.; Liu, C.; Livshits, E.; Baer, R.; Neuhauser, D. Electrical or photocontrol of the rotary motion of a metallacarborane. Science 2004, 303, 1849-1851. [CrossRef]

6. Safronov, A.V.; Shlyakhtina, N.I.; Everett, T.A.; VanGordon, M.R.; Sevryugina, Y.V.; Jalisatgi, S.S.; Hawthorne, M.F. Direct observation of bis(dicarbollyl)nickel conformers in solution by fluorescence spectroscopy: An approach to redox-controlled metallacarborane molecular motors. Inorg. Chem. 2014, 53, 10045-10053. [CrossRef] [PubMed]

7. Shlyakhtina, N.I.; Safronov, A.V.; Sevryugina, Y.V.; Jalisatgi, S.S.; Hawthorne, M.F. Synthesis, characterization, and preliminary fluorescence study of a mixed-ligand bis(dicarbollyl)nickel complex bearing a tryptophanBODIPY FRET couple. J. Organomet. Chem. 2015, 798, 234-244. [CrossRef]

8. Anufriev, S.A.; Suponitsky, K.Y.; Filippov, O.A.; Sivaev, I.B. Synthesis and structure of methylsulfanyl derivatives of nickel bis(dicarbollide). Molecules 2019, 24, 4449. [CrossRef]

9. Spokoyny, A.M.; Li, T.C.; Farha, O.K.; Machan, C.W.; She, C.; Stern, C.L.; Marks, T.J.; Hupp, J.T.; Mirkin, C.A. Electronic tuning of nickel-based bis(dicarbollide) redox shuttles in dye-sensitized solar cells. Angew. Chem. Int. Ed. 2010, 49, 5339-5343. [CrossRef]

10. Li, T.C.; Spokoyny, A.M.; She, C.; Farha, O.K.; Mirkin, C.A.; Marks, T.J.; Hupp, J.T. Ni(III)/(IV) bis(dicarbollide) as a fast, noncorrosive redox shuttle for dye-sensitized solar cells. J. Am. Chem. Soc. 2010, 132, 4580-4582. [CrossRef]

11. Kung, C.-W.; Otake, K.; Buru, C.T.; Goswami, S.; Cui, Y.; Hupp, J.T.; Spokoyny, A.M.; Farha, O.K. Increased electrical conductivity in a mesoporous metal-organic framework featuring metallacarboranes guests. J. Am. Chem. Soc. 2018, 140, 3871-3875. [CrossRef]

12. Warren, L.F.; Hawthorne, M.F. Chemistry of the bis[ $\pi$-(3)-1,2-dicarbollyl] metalates of nickel and palladium. J. Am. Chem. Soc. 1970, 92, 1157-1173. [CrossRef]

13. Maier, N.A.; Erdman, A.A.; Zubreichuk, Z.P.; Prokopovich, V.P.; Ol'dekop, Y.A. Synthesis and some transformations of complex nickel(II) salts of bis(3,1,2-dicarbollyl)nickel(III). Preparation of 3-(2,2' bipyridyl)-closo-3,1,2-nickeladicarbadodecaborane. J. Organomet. Chem. 1985, 292, 297-302. [CrossRef]

14. Zubreichuk, Z.P.; Erdman, A.A.; Ivko, A.A.; Maier, N.A. Synthesis and some transformations of complex salts of bis-o-dicarbollyliron(II), -cobalt(II), and -nickel(II). Russ. J. Gen. Chem. 2001, 71, 531-534. [CrossRef]

15. Erdman, A.A.; Zubreichuk, Z.P.; Knizhnikov, V.A.; Maier, A.A.; Aleksandrov, G.G.; Nefedov, S.E.; Eremenko, I.L. Synthesis and the structure of the triphenylphosphine complex of $o$-nickelacarborane, 3,3-( $\left.\mathrm{PPh}_{3}\right)_{2}-3,1,2-\mathrm{NiC}_{2} \mathrm{~B}_{9} \mathrm{H}_{11}$. Russ. Chem. Bull. 2001, 50, 2248-2250. [CrossRef]

16. Andreichuk, E.P.; Anisimov, A.A.; Shmalko, A.V.; Suponitsky, K.Y.; Sivaev, I.B.; Bregadze, V.I. Stability of nickel bis(dicarbollide) complexes. Mendeleev Commun. 2019, 29, 534-536. [CrossRef]

17. Viñas, C.; Pedrajas, J.; Teixidor, T.; Kivekäs, R.; Sillanpää, R.; Welch, A.J. First example of a bis(dicarbollide) metallacarborane containing a B,C'-heteronuclear bridge. Inorg. Chem. 1997, 36, 2988-2991. [CrossRef] [PubMed]

18. Planas, J.G.; Viñas, C.; Teixidor, F.; Light, M.E.; Hursthouse, M.B. A boron-boron linked large metallacarborane cluster: Characterization and X-ray structure of $8,9^{\prime}-\left[\text { closo- }\left\{3-\mathrm{Co}\left(\eta^{5}-\mathrm{C}_{5} \mathrm{H}_{5}\right)-1,2-\mathrm{C}_{2} \mathrm{~B}_{9} \mathrm{H}_{10}\right\}\right]_{2}$. J. Organomet. Chem. 2006, 691, 3472-3476. [CrossRef]

19. Molotkov, A.P.; Vinogradov, M.M.; Moskovets, A.P.; Chusova, O.; Timofeev, S.V.; Fastovskiy, V.A.; Nelyubina, Y.V.; Pavlov, A.A.; Chusov, D.A.; Loginov, D.A. Iridium halide complexes [1,1- $\left.\mathrm{X}_{2}-8-\mathrm{SMe}_{2}-1,2,8-\mathrm{IrC}_{2} \mathrm{~B}_{9} \mathrm{H}_{10}\right]_{2}(\mathrm{X}=\mathrm{Cl}, \mathrm{Br}, \mathrm{I})$ : Synthesis, reactivity and catalytic activity. Eur. J. Inorg. Chem. 2017, 4635-4644. [CrossRef]

20. Jeans, R.J.; Chan, A.P.Y.; Riley, L.E.; Taylor, J.; Rosair, G.M.; Welch, A.J.; Sivaev, I.B. Arene-ruthenium complexes of 1,1'-bis(ortho-carborane): Synthesis, characterization, and catalysis. Inorg. Chem. 2019, 58, 11751-11761. [CrossRef]

21. Chan, A.P.Y.; Parkinson, J.A.; Rosair, G.M.; Welch, A.J. Bis(phosphine)hydridorhodacarborane derivatives of $1,1^{\prime}$-bis(ortho-carborane) and their catalysis of alkene isomerization and the hydrosilylation of acetophenone. Inorg. Chem. 2020, 59, 2011-2023. [CrossRef]

22. Chan, A.P.Y.; Rosair, G.M.; Welch, A.J. Exopolyhedral ligand orientation controls diastereoisomer in mixed-metal bis(carboranes). Molecules 2020, 25, 519. [CrossRef] 
23. Churchill, M.R.; Gold, K. Geometry of the $\left(\mathrm{B}_{8} \mathrm{C}_{2} \mathrm{H}_{10} \cdot \mathrm{C}_{5} \mathrm{H}_{5} \mathrm{~N}^{2-}\right)$ anion from an $X$-ray structural analysis of $\left[\mathrm{Et}_{4} \mathrm{~N}^{+}\right]\left[\left(\mathrm{B}_{9} \mathrm{C}_{2} \mathrm{H}_{11}\right) \mathrm{Co}\left(\mathrm{B}_{8} \mathrm{C}_{2} \mathrm{H}_{10} \cdot \mathrm{C}_{5} \mathrm{H}_{5} \mathrm{~N}\right)^{-}\right]$. J. Chem. Soc. Chem. Commun. 1972, 901-902. [CrossRef]

24. Meshcheryakov, V.I.; Kitaev, P.S.; Lyssenko, K.A.; Starikova, Z.A.; Petrovskii, P.V.; Janoušek, Z.; Corsini, M.; Laschi, F.; Zanello, P.; Kudinov, A.R. (Tetramethylcyclobutadiene)cobalt complexes with monoanionic carborane ligands $\left[9-\mathrm{L}-7,8-\mathrm{C}_{2} \mathrm{~B}_{9} \mathrm{H}_{10}\right]^{-}\left(\mathrm{L}=\mathrm{SMe}_{2}, \mathrm{NMe}_{3}\right.$ and py). J. Organomet. Chem. 2005, 690, 4745-4754. [CrossRef]

25. Buades, A.B.; Arderiu, V.S.; Olid-Britos, D.; Viñas, C.; Sillanpää, R.; Haukka, M.; Fontrodona, X.; Paradinas, M.; Ocal, C.; Teixidor, F. Electron accumulative molecules. J. Am. Chem. Soc. 2018, 140, 2957-2970. [CrossRef] [PubMed]

26. Bader, R.F.W. Atoms in Molecules. A Quantum Theory; Clarendon Press: Oxford, UK, 1990.

27. Keith, T.A. AIMAll (Version 15.05.18); TK Gristmill Software: Overland Park, KS, USA, 2015.

28. Espinosa, E.; Molins, E.; Lecomte, C. Hydrogen bond strengths revealed by topological analyses of experimentally observed electron densities. Chem. Phys. Lett. 1998, 285, 170-173. [CrossRef]

29. Anufriev, S.A.; Sivaev, I.B.; Suponitsky, K.Y.; Godovikov, I.A.; Bregadze, V.I. Synthesis of 10-methylsulfide and 10-alkylmethylsulfonium nido-carborane derivatives: B-H $\cdots \pi$ Interactions between the B-H-B hydrogen atom and alkyne group in 10- $\mathrm{RC} \equiv \mathrm{CCH}_{2} \mathrm{~S}(\mathrm{Me})-7,8-\mathrm{C}_{2} \mathrm{~B}_{9} \mathrm{H}_{11}$. Eur. J. Inorg. Chem. 2017, 4436-4443. [CrossRef]

30. Dmitrienko, A.O.; Karnoukhova, V.A.; Potemkin, A.A.; Struchkova, M.I.; Kryazhevskikh, I.A.; Suponitsky, K.Y. The influence of halogen type on structural features of compounds containing $\alpha$-halo- $\alpha, \alpha$-dinitroethyl moieties. Chem. Heterocycl. Comp. 2017, 53, 532-539. [CrossRef]

31. Sheremetev, A.B.; Aleksandrova, N.S.; Semyakin, S.S.; Suponitsky, K.Y.; Lempert, D.B. Synthesis and characterization of 3-(5-(Fluorodinitromethyl)-1H-1,2,4-triazol-3-yl)-4-nitrofurazan: A novel promising energetic component of boron-based fuels for rocket ramjet engines. Chem. Asian J. 2019, 14, 4255-4261. [CrossRef] [PubMed]

32. Taoda, Y.; Sawabe, T.; Endo, Y.; Yamaguchi, K.; Fujii, S.; Kagechika, H. Identification of an intermediate in the deboronation of ortho-carborane: An adduct of ortho-carborane with two nucleophiles on one boron atom. Chem. Commun. 2008, 2049-2051. [CrossRef]

33. Jones, C.J.; Francis, J.N.; Hawthorne, M.F. New 10- and 11-atom polyhedral metallocarboranes prepared by polyhedral contraction. J. Am. Chem. Soc. 1972, 94, 8391-8399. [CrossRef]

34. Jones, C.J.; Francis, J.N.; Hawthorne, M.F. Derivative chemistry of metallocarboranes. nido 11-Atom metallocarboranes and their Lewis base adducts. J. Am. Chem. Soc. 1973, 95, 7633-7643. [CrossRef]

35. Pisareva, I.V.; Dolgushin, F.M.; Tok, O.L.; Konoplev, V.E.; Suponitsky, K.Y.; Yanovsky, A.I.; Chizhevsky, I.T. Small metallacarborane closo- $\mathrm{C}_{2} \mathrm{~B}_{4} \mathrm{H}_{6} \mathrm{Ru}\left(\mathrm{PPh}_{3}\right)_{2} \mathrm{HCl}$ formed from nido-5,6- $\mathrm{C}_{2} \mathrm{~B}_{8} \mathrm{H}_{12}$ by ruthenium- mediated polyhedral contraction. Organometallics 2001, 20, 4216-4220. [CrossRef]

36. Konoplev, V.E.; Tachaev, M.V.; Ulyukina, E.A. "Polyhedral contraction" of tetramethylammonium closo-carboundecaborate underaction of tris(triphenylphosphine)ruthenium dichloride. Izv. Vyssh. Uchebn. Zaved. Khim. Khim. Tekhnol. 2020, 63, 26-32. [CrossRef]

37. Hawthorne, M.F.; Young, D.C.; Andrews, T.D.; Howe, D.V.; Pilling, R.L.; Pitts, A.D.; Reintjes, M.; Warren, L.F.; Wegner, P.A. $\pi$-Dicarbollyl derivatives of the transition metals. Metallocene analogs. J. Am. Chem. Soc. 1968, 90, 879-896. [CrossRef]

38. APEX2 and SAINT; Bruker AXS Inc.: Madison, WI, USA, 2014.

39. Sheldrick, G.M. Crystal structure refinement with SHELXL. Acta Cryst. C 2015, 71, 3-8. [CrossRef] [PubMed]

Publisher's Note: MDPI stays neutral with regard to jurisdictional claims in published maps and institutional affiliations.

(C) 2020 by the authors. Licensee MDPI, Basel, Switzerland. This article is an open access article distributed under the terms and conditions of the Creative Commons Attribution (CC BY) license (http://creativecommons.org/licenses/by/4.0/). 